\title{
Analysis of the Impact of the Cage Type on the Frictional Moment Ball Bearings
}

\author{
Łukasz Gorycki \\ Department of Manufacturing Engineering and Metrology, Kielce University of Technology, Kielce 25-314 al. Tysiqclecia Państwa \\ Polskiego 7, Poland
}

\begin{abstract}
The paper presents the methodology and results of measurement designed to determine the effect of the rolling element separator (cage) at the frictional moment in ball bearings. The measurement was carried out on four groups on bearing with different cages. Measurements were carried out on torque-meter STPM, a device that has been designed and manufactured at Kielce University of Technology. The measurement results showed that the type of cage used in ball bearings has a significant impact on the frictional moment. In addition, the results also confirm that the size of the curvature ratio and the accuracy of the races shape have a significant impact on the frictional moment.
\end{abstract}

Key words: Rolling bearing, bearing test, resistive torque, cage.

\section{Introduction}

In order to maximize the reliability of equipment, the manufacturers are forced to systematic improvement their products. The changes apply to the design, manufacturing technology, maintenance and optimization selection of elements. For bearings, this selection mainly depends on the work conditions in which they will be used. After determining the operating conditions, the bearings are selected based on design parameters such as: bearing type, size, clearance, type of rolling element separator, lubrication, etc., and taking into account the operational parameters, such as: capacity, speed limits, frictional moment, rotation accuracy, noise, etc. Bearing life and reliability are crucial for the machines operation in which they are used. Premature wear or damage to the bearings, is associated with a time-consuming and costly replacement. This is particularly important in the case of large-size bearings used for supporting large cylindrical elements [1]. One of the most important factors

Corresponding author: Łukasz Gorycki, M.Sc., research fields: rolling bearing, resistive torque, track shape. E-mail: lgorycki@tu.kielce.pl. determining the bearing life is the frictional moment. It shows the levels of energy losses. This energy is lost as heat or to the destruction of the lubricant and the bearing cooperating surfaces. This moment depends on many factors, both those related to the bearing design parameters applied lubricant and working conditions of the bearing. Although the qualitative impact of each factor on the frictional moment is known, their numerical contribution to the final result has not been full examined yet, and not all of these factors are taken into account in the mathematical relationships use. This paper dealt with analysis of the impact of rolling element separator type on the frictional moment.

Rolling elements separator (cage) is a bearing element that is use to separate the rolling elements (balls, cones, etc.), in order to avoid friction between them, and their even positioning on the periphery of the bearing. During the work of the bearing, the cage may come in contact with the rolling elements and the rings. In places the contact the size of friction that occurs will depend on the work conditions and the shape and material from which the cage was made. The material used for the manufacture of cage 
depends mainly on the type of bearings in which it will be used. The cage may be made from carbon steel, brass, plastic or synthetic resin [2].

Frictional moment is the result of the energy losses in the area of co-operation of the rolling elements with the races and the cage, as well as losses resulting from wading in the means of rolling elements lubricants. The larger the frictional moment of the working bearing is, the shorter its life will be. Therefore, users of bearings want to be able to select the most appropriate bearing to specific conditions. In order to determine the theoretical frictional moment in rolling bearings mainly two mathematical relationships are used, the mathematical relationships are described in Eqs. (1) and (5).

Frictional moment formula according to Palmgren'a [3]:

$$
\begin{gathered}
M=M_{0}+M_{1} \\
\text { for } v \times n \geq 2,000 \\
M_{0}=10^{-7} \cdot f_{0} \cdot(v \times n)^{2 / 3} \cdot d_{m}{ }^{3} \\
\text { for } v \times n<2,000 \\
M_{0}=1.6 \cdot 10^{-5} \cdot f_{0} \cdot d_{m}{ }^{3} \\
M_{1}=f_{1} \cdot P_{1} \cdot d_{m}
\end{gathered}
$$

where, $M_{0}$-torque losses caused by friction and wading in the lubricants, $(\mathrm{Nmm})$ (represented by the Eqs. (2) and (3)); $M_{1}$-torque taking into account the contact size of the rolling elements and the races, resulting from the load and the intensity of the phenomena occurring in these areas (Nmm) (represented by the dependence 4).

$$
\begin{aligned}
& n \text {-rotation speed }\left(\mathrm{min}^{-1}\right) ; \\
& v \text { - kinematic viscosity }\left(\mathrm{m}^{2} \cdot \mathrm{s}^{-1}\right) \text {; }
\end{aligned}
$$

$f_{0}$ - coefficient depending on the bearings type and lubricating method;

$d_{m}$ - bearing pitch diameter $(\mathrm{mm})$;

$f_{1}$ - coefficient depending on the type of bearing and the load;

$P_{1}$ - coefficient depending on the type of bearing and the load $(\mathrm{N})$.

Frictional moment formula according to SKF [4]

$$
M=M_{r r}+M_{s l}+M_{\text {seal }}+M_{\text {drag }}
$$

where, $M$-total frictional moment (Nmm); $M_{r r}$-rolling frictional moment $(\mathrm{Nmm}) ; M_{s l}$-sliping frictional moment $(\mathrm{Nmm}) ; M_{\text {seal }}$-seals frictional moment (Nmm); $M_{\text {drag }}$-frictional moment resulting from resistance to motion in the oil, grease kneading, splashing etc. (Nmm).

The mathematical relationships take into account many factors which influence the frictional moment but not all of them. In addition to the aforementioned type of cage, these models do not take into account the curvature ratio and the accuracy of the implementation of the races shape (errors shape, waviness and roughness). The results in Ref. [5] show curvature ratio in difficult conditions (high load and speed) has a clear effect on the moment resistance of the working bearings.

The frictional moment measurements were performed in 3 series on torque-meter STPM shown in Fig. 1.

\section{Research Equipment}

In order to analyze the impact of the cage at the frictional moment, a series of measurements was performed on torque-meter STPM [6]. The torque-meter was designed at Kielce University of Technology and is a response to the needs of industry for equipment for frictional moment in rolling bearings [7]. It provides the ability to perform frictional moment measurements on small and medium sized roller bearings.

\section{Measurement}

The tests were performed on the following four bearing samples:

- Sample A: 6202A8, plastic cage;

- Sample B: 6202A8, metal cage;

- Sample C: 6202A17, plastic cage;

- Sample D: 6202A17 metal cage.

Each bearing sample consists of 10 items. Samples not only have different cages, but also have differed races shape. $6202 \mathrm{~A} 8$ bearings have a larger radius of the races then the 6202A17 bearings. Each bearing 


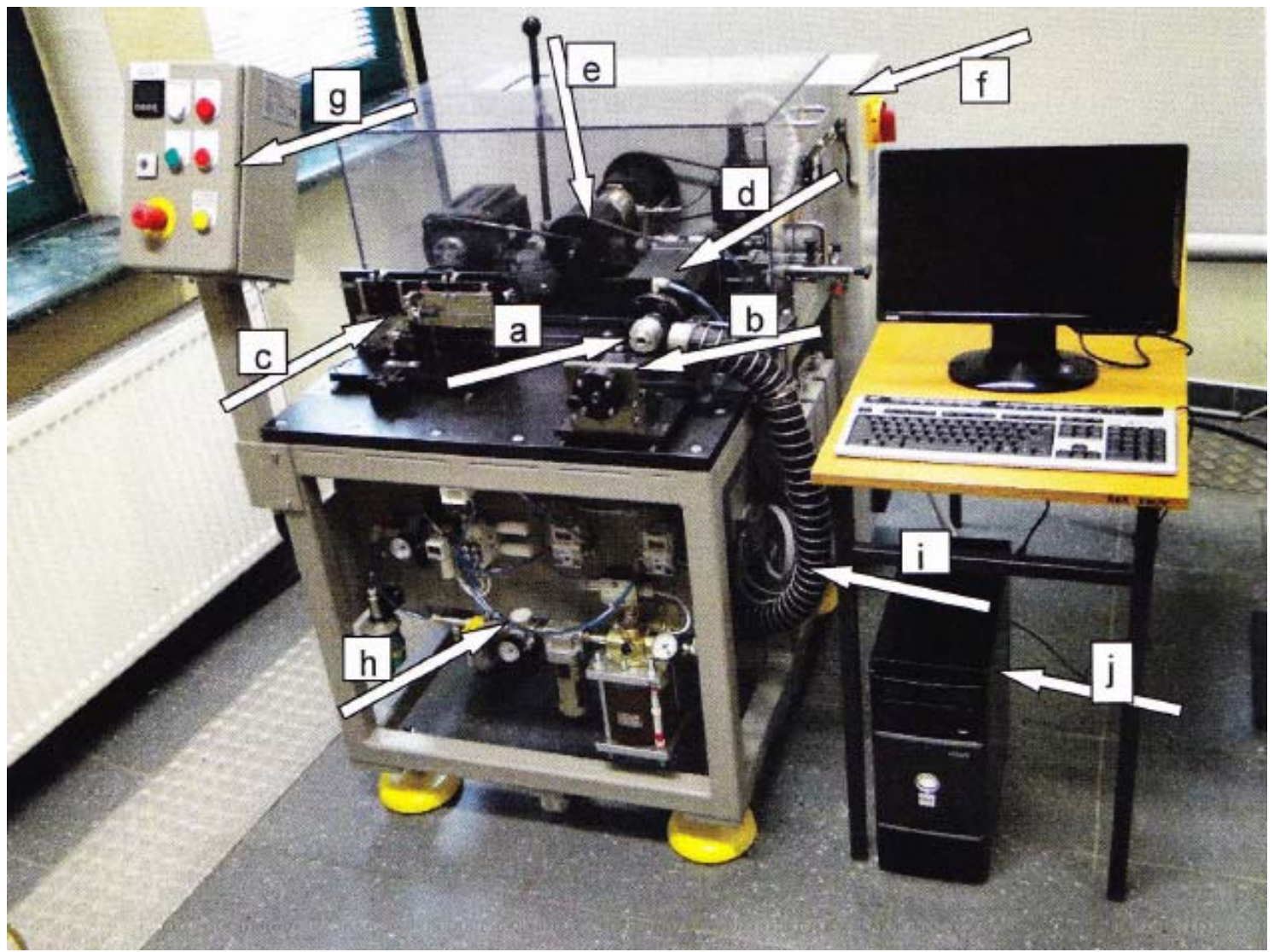

Fig. 1 The torque-meter STPM use in the Rolling Bearing Research Laboratory at Kielce University of Technology: (a) probe; (b) axial load; (c) radial load; (d) research spindle; (e) driving gear; (f) the control box; (g) control panel; (h) the pneumatic supply unit; (i) blow; and (j) PC.

Table 1 Parameters for three series of measurements.

\begin{tabular}{llll}
\hline & 1 Series & 2 Series & 3 Series \\
\hline Axial load (N) & 10 & 180 & 180 \\
Radial load (N) & 0 & 300 & 400 \\
Rotation speed $\min ^{-1}$ & 15,000 & 15,000 & 20,000 \\
\hline
\end{tabular}

Table 2 Measurement results of frictional moment (Nmm), for the 4 bearing groups in each measurement series.

\begin{tabular}{llll}
\hline & 1 Series & 2 Series & 3 Series \\
\hline Sample A & 14,278 & 48,746 & 82,011 \\
Sample B & 26,218 & 102,713 & 124,815 \\
Sample C & 20,660 & 53,238 & 81,897 \\
Sample D & 38,111 & 108,335 & 132,098 \\
\hline
\end{tabular}

was measured twice, in each measurement the axial load was acting with the same magnitude but in a opposing direction before each measurement, in order to secure the bearing and minimizing the effect of lubricant on the frictional moment, a same small amount of Drosera MS 10 oil, was added to the bearings. For each sample, three series of measurements were performed. Each is with different values of the axial load, radial and rotational speed. The magnitudes of these parameters are shown in Table 1.

The results of frictional moment measurement, measured in three series obtained for four samples of bearings are shown in Table 2 .

\section{Conclusions}

The results of the experiment presented in this paper confirm the significant impact of the material used to make the cage in the ball bearings on the frictional moment. Ball bearings with metal cages generate more frictional moment then the bearings with plastic cages. This is due to differences in the friction coefficients, cage weight or the contact surfaces (plastic baskets have a lower friction coefficient and are much lighter than steel baskets).

The changes of the frictional moment value in the 
following series of measurements, show a similar behavior of the bearings in relation to the changing research condition: the speed of rotation, radial and axial loads. Only in sample $\mathrm{C}$, the characteristics are different than in the other sample (for example in the 3 series the frictional moment measurement result for the sample $\mathrm{C}$ should be greater than those obtained for sample A), this suggesting that in addition to the cage type and the curvature ratio, other parameters lick the accuracy of its performance (e.g., wave profile or race deviation) could have a significant impact on the results of sample $\mathrm{C}$ bearings.

\section{References}

[1] Nozdrzykowski, K., and Janecki, D. 2014. "Comparative Studies of Reference Measurements of Cylindrical Surface
Roundness Profiles of Large Machine Components." Metrology and Measurement Systems XXI (1): 67-76.

[2] NSK. 2005. Motion \& Control. Technical Report.

[3] Krzemiński-Frede H. Łożyska toczne. PWN, Warszawa 1989.

[4] Katalog produkcyjny SKF, 2011.

[5] Gorycki Ł., Domagalski R., Zmarzły P. Pomiary momentów oporowych łożysk tocznych w aspekcie dokładności kształtowo - wymiarowej elementów współpracujących. Mechanik nr. 3, 2015. ISSN 0025-6552.

[6] Janecki, D. Instrukcja obsługi programu do pomiaru statycznego i dynamicznego momentu oporowego w łożyskach "Momentomierz". Politechnika Świętokrzyska. Kielce 2014.

[7] Adamczak, S. Domagalski, R. Sender, E. Metody badań łożysk tocznych $\mathrm{w}$ aspekcie współczesnych wymagań wyrobów o wyższych parametrach eksploatacyjnych. Tribologia, 2011, nr 6, s 11-18. 